\author{
Kazakov . $^{1}$ \\ ${ }^{1}$ KazNU named after Al-Farabi \\ Almaty, Kazakhstan
}

\title{
MIGRATION SENTIMENTS OF KAZAKHSTANI YOUTH IN THE CONTEXT OF EDUCATIONAL MIGRATION
}

\begin{abstract}
This article is part of a study of educational migration from Kazakhstan. It analyzes the degree of influence of social, cultural, economic aspects on the migration mood of Kazakhstani youth in the real socio-economic conditions of Kazakhstani society. A number of push factors, or systemic problems of the public and private sectors, provoking a massive flow of educational migrants from the Republic are considered. On the basis of the collected statistical information, personal motives, preferences and social trends are determined in the formation of the migration flow. A survey was conducted to identify current migration intentions and attitudes of Kazakhstani youth. The priority directions of migration in the context of the global systemic crisis are studied.
\end{abstract}

Key words: migration behavior, educational migration, migration flow, youth attitudes, social motive, economic crisis.

\author{
Казаков В. Ю. ${ }^{1}$ \\ ${ }^{1}$ Аль-Фараби атындавы ҚазҰУ- $i$ \\ Алиаты, Қазақ̧стан
}

\section{БІЛІМ БЕРУ КӨШІҚОНЫ ЖАҒДАЙЫНДАҒЫ ҚАЗАҚСТАНДЫҚ ЖАСТАРДЫН КӨШІ-КОНДЫ ҚОЗДЫРАТЫН ФАКТОРЛАРЫ}

\section{Аң̧датпа}

Бұл мақала Қазақстаннан білім беру көші-қонын зерттеуге арналған. Онда әлеуметтік, мәдени, экономикалық аспектілердің қазақстандық қоғамның нақты әлеуметтік, экономикалық жағдайындағы қазақстандық жастардың көші-қон көңіл-күйіне әсер ету дәрежесі талданады. Бірқатар итермелейтін факторлар немесе республикадан білім мигранттарының көптеп келуіне себеп болатын мемлекеттік және жеке сектордың жүйелік мәселелері қарастырылады. Жиналған статистикалық ақпарат негізінде көші-қон ағынының қалыптасуындағы жеке себептер, қалаулар және әлеуметтік бағыттар анықталады. Қазақстандық жастардың көші-қон ниеттері мен көзқарастарын анықтау мақсатында сауалнама жүргізілді. Әлемдік жүйелік дағдарыс жағдайында көші-қонның басым бағыттары зерттелген.

Түйін сөздер: көші-қон мінез-құлқы, білім беру көші-қоны, көші-қон ағымы, жастардың көзқарасы, әлеуметтік мотив, экономикалық дағдарыс.

Казаков В.Ю. ${ }^{1}$

${ }^{1}$ Казахский Национальньй Университет имени аль-Фараби

Алматы, Казахстан

МИГРАЦИОННЫЕ НАСТРОЕНИЯ КАЗАХСТАНСКОЙ МОЛОДЕЖИ

В КОНТЕКСТЕ ОБРАЗОВАТЕЛЬНОЙ МИГРАЦИИ

Аннотация 
Данная статья является частью исследования образовательной миграции из Казахстана. В ней проанализирована степень влияния социальных, культурных, экономических аспектов на миграционные настроения казахстанской молодежи в реальных социально-экономических условиях казахстанского общества. Рассматривается ряд выталкивающих факторов, или системных проблем государственного и частного секторов, провоцирующих массовый поток образовательных мигрантов из Республики. На основе собранной статистической информации, определены личные мотивы, предпочтения и общественные тенденции при формировании миграционного потока. Проведено анкетирование молодых людей с целью выявления актуальных миграционных намерений, и установок казахстанской молодежи. Изучены приоритетные направления миграции в контексте глобального системного кризиса.

Ключевые слова: миграционное поведение, образовательная миграция, миграционный поток, установки молодежи, социальный мотив, экономический кризис.

Migration sentiments of Kazakhstan youth in the context of educational migration

The migration process is studied by representatives of sociology, demographics, economics, political science, psychology, religious studies, cultural studies. The research comprises practical and theoretical researches of the period of independent Kazakhstan humanitarian science. Recently, educational migration has also come under the scrutiny of the expert and scientific communities. In general, trends in social studies confirm the urgency of the problem of migration from Kazakhstan. There is an order from the state and civil institutions to study this phenomenon. In addition, the world economy is in recession, crisis phenomena, uncertainty of the future of entire regions of the globe stimulate migration. The systemic nature of the crisis generates asset depreciation, the only asset not subject to inflationary influence is a highly qualified, human resource. However, the ability to control the movement of this resource is very limited. They are due to the economic development of the region, the availability of jobs in the national economy, social prospects for the individual and his family members in society, and the adequacy of the national and language policy pursued by the state.

Migration, including educational migration, is an indicator of the socio-economic development of the country, an indicator of psychological satisfaction with life (happiness ratio). It is also a way to improve the quality of human capital. An opportunity to transfer advanced technology and knowledge. The modern stage of world scientific, technical and socio-economic development is characterized by a fundamental change in the role and importance of the human factor in the economy and in society. Human capital becomes the most important factor of economic growth and determines the future of the country [1].

The struggle for human resources has reached a global level. Every country aspires to development. Attracting highly skilled workers has become a trend. This is how the economies of the most developed countries were built. Kazakhstan's economy actively attracts foreign personnel to solve many systemic problems. This applies to medicine, education, science, culture, sports. In this regard, the training of domestic specialists is a priority state task. Almost the entire period of independence is undergoing various kinds of reforms. The main task of public policy is to create a competitive education system, and a system for importing technologies, knowledge and personnel.

Educational migrants are becoming carriers of new knowledge and technology. In Western social science, students who have crossed the borders of their national states for education purposes, are classified as mobile or international students. Educational migration is a migration flow caused by higher education. The expanded format of such a flow - educational migration, includes not only students (masters, bachelors, specialists), but also graduate students, doctoral students, students of preparatory courses, i.e. is a migration flow, in the purpose of the gaining of all levels within the system of higher and postgraduate education [2]. According to the UNESCO Institute of Statistics for 2014, about 207 million people receive higher education in the world, about 5 million of them are mobile students, or $2 \%$ of the total, by 2025 , according to the forecast of the same institute, the number of foreign students will reach 7.5 million, and [3]. The number of foreign students is growing. The number of citizens studying outside Kazakhstan reaches about 130,000 people.

Pushing and attracting factors of educational migration

When considering the migration mechanism, there are factors of push-out and attraction that are of an economic, demographic, social and political nature. 
The "pull/push" theory was put forward in 1966 by American scientist Everett Lee [4]. The unit of analysis on this theory of international and internal migration of all kinds is the individual.

Factors influencing the decision to decide on migration can be combined into four groups: the regionrelated migrant departures; Related to potential migrant arrivals region; Intervening circumstances; factors related to the subjective characteristics of migrants (personal factors).

Among the factors in the first two groups, in each region, there are reasons that keep the population in the area (neutral-factor), push it (push-factor) or attract (pull-factor)2. The decision on migration is made under the influence of the factors of ejection in the country of residence and the attraction emanating from a potential country of emigration.

In the region of arrival, the determining role in the migration movement is given to attractive factors, and in the region of departure - to the ejecting factors.

At the macro level, the use of this theory allows us to take into account the socio-economic conditions in the donor country and the recipient country. The greater the difference in social, economic or political conditions in the two regions, the more likely it is that migration is under the influence of the forces of attraction to areas with better conditions [5].

The ejection factors that have led to the modern migration behavior of Kazakhstan's youth can be divided into two main groups: socio-economic, cultural, and communication.

Factors of the push-out migration are a set of social and political phenomena and processes that stimulate the formation of migration attitudes and intentions of the citizen.

Migration intention is a stable psychological attitude that encourages the individual to actually change the country of residence.

Intentions are shaped by external cultural, political, socio-economic factors of the habitat. Migration behaviour is formed from the complex of migration intentions. For example, sustainable youth migration to regional centers and cities of national importance for obtaining secondary-special and higher national education.

Socio-economic pushing factors are a set of negative trends that create a tense atmosphere within society. These include:

1. Lack of demand in the labor market, low wages, rising economic inequality, unsafe production conditions;

2. the situation with the rights and freedoms of the citizen, the level of protection of property rights;

3. systemic problems of the state: corruption, bureaucracy and quality of management, tribalism;

4. demographic and migration growth of the Kazakh population, and emigration of other nationalities;

5. dissatisfaction with the infrastructure and quality of educational and medical services in Kazakhstan.

Cultural and communication-pushing factors are a complex of ideological problems that contribute to the migration of students for education. These include:

1. General low cultural level, periphery and conservatism of public consciousness;

2. Information factors that allow people to learn about opportunities and prospectives abroad;

3. Public policy in the sphere of nation, language, religion;

4. general socio-political environment, lack of social ties, and prospects for starting a family;

5. lack of prospects for self-development, poor overall well-being of people, and poor environmental status.

The ejection factors of educational migration reflect socio-economic problems. Increased social tension leads to increased migration behaviour among young people. Increasingly, children themselves insist on studying abroad. It has become fashionable, affordable, prestigious to have a foreign diploma. There was an opportunity to gain social connections.

The ejection factors work for migration along with attractives. It is wrong to say that only the unsettledness of Kazakhstan's reality pushes people to migrate. Often attractive factors play an important role. They can also be divided into two main groups: socio-economic, cultural and communicative.

Socio-economic factors:

1. Low competition in the labor market, high wages, lack of sense of economic inequality, safe production conditions;

2. protection of the rights of the owner and the citizen, in a developed civil society, and a transparent state;

3. lack of corruption and bureaucracy at the grass-roots level, quality of public services and governance; 
4. a comfortable social environment;

5. high level of urban infrastructure and quality of educational and medical services.

Cultural and communication factors of the recipient's country:

1. The general high cultural level of the population, the liberalism of public consciousness, Western liberal values and proximity to the cultural regions of the world;

2. marketing information techniques, to promote foreign education;

3. public policy in the sphere of nation, language, religion;

4. a general socio-political environment, social links, and prospects for starting a family;

5. prospects for self-development, high levels of human well-being and an acceptable state of the environment.

In the study of migration factors, it is important to clearly define the role of the state and civil society in migration processes. The consciousness of modern youth is under constant psychological pressure. Considering the risks and consequences of educational migration, developing sound policies are the priorities for the scientific community and government.

General trends in the flow of educational migration

Every year in Kazakhstan, about 120,000 people become high school graduates. 20 per cent of that number, or one in five matriculant, become a student of a foreign university. In 2017-2018 academic year about 130,000 Kazakhstan students of undergraduate, master's, doctoral, internship are studying abroad. The geography of the main student flows is very diverse and covers about 50 countries. The most popular destinations, among the domestic entrants, are Russia, China, EU countries, USA, and Canada. The main areas are the Russian Federation and the People's Republic of China, which account for about $85 \%$ of the students. Thus, the main problem of this study is the question: under the influence of what reasons Russia and China have become the main priority areas of educational migration from Kazakhstan? The answer to this research question will allow to conduct a qualitative analysis of the intra-system problems of the national education system.

The structure of the study is as follows. First, the volume of migration flows to Russia and China was considered, and a qualitative analysis of quantitative data on educational levels was carried out. Further, the main causes and factors of migration of students from Kazakhstan have been identified. Finally, the findings and results of the study are presented, together with a final discussion of the possibilities for future research within the problem.

Behind the choice of geography of education for Kazakhstan youth are both personal or private reasons, and general trends. As of 2018, approximately 130,000 students are studying abroad. Among those students, students of full-time undergraduate, master's and PhD degrees are approximately 100,000 and about 30,000 are studying remotely, which means that they have not left the country, and therefore do not belong to mobile students [6].

Direction Number of students

Russian Federation 70740

People's Republic of China 17600

Kyrgyz Republic 4357

United States 2144

United Kingdom 1925

Czech Republic 1314

Germany 995

Other 6115

Just 101845

According to the Ministry of Education of the Russian Federation and China for the 2017-2018 academic year: 70,000 people are studying in Russia [7, about 14,000 or $15 \%$ of them are studying in China[8]. It turns out that a large enough number of students in search of knowledge in the nearest neighbors.

As an example, in Russia, one in four international students of both part-time and full-time study is from Kazakhstan [9].

At the same time, in China, about $4 \%$ of the total number of students are citizens of Kazakhstan. Such data suggest the question: why is there such a big skew in favor of our closest neighbors? The main answer is the close geographical location of the two countries, economic expediency, cultural proximity (as far as Russia is concerned), but there are also several socio-economic, cultural, and other reasons. 
The following table presents data on educational migration in China and the Russian Federation for the last 5 years, taking into account the levels of education: preparatory or language courses, bachelor's, master's degree, doctorate (graduate school) to the table attached schedule.

International students, thousands of people 20112012201320142015

China 8,5 10,1 11,2 12,5 14,0

Language and preparatory courses $3,13,54,24,65,0$

Bachelor 4,5 5,3 6,0 6,7 7,8

Master 0,6 0,85 0,9 0,8 0,9

Doctorate $0,30,450,30,40,3$

Russia 37,6 46,7 54,5 65,1 70,7

Preparatory courses

(trained in branches in Kazakhstan) $1,11,31,41,41,5$

Bachelor 32,5 38,9 46,1 55,0 59,1

Master 6,0 6,0 6,1 7,2 9,1

$\mathrm{PhD}$ (graduate school) $0,50,50,81,61,0$

From the data above it is clear that the flow of students from Kazakhstan to China and Russia is increasing every year, while it has been steadily growing over the past 5 years, with an annual stable growth in the corridor of $7-15 \%$, with slight declines and rises.

As for China, the statistics show an interesting fact that after 2012, the growth of students leaving for China is stable at the same level, which is most likely due to the activities of commercial organizations offering services to accompany the student in the process of enrollment in Chinese universities. It is also worth noting that there is almost no increase in the number of students enrolled in the levels of master's and doctoral studies, which is most likely due to the high cost of these programs, and the desire to enter the budget places, and the number of grants for international students remains at the same level. For the record, to study in China on the basis of the budget requires the presence of a language certificate, either English or Chinese, in this regard, a huge number of students undergo almost mandatory preparatory courses, and their number is growing. But here the question arises, why does not increase the number of students in the bachelor's degree? Most likely, the reason is that many of the students receive unsatisfactory points in Chinese, so they remain for a second year of study, or refuse to continue their studies in China. By the way, statistics on this topic are available for the totality of all international students, but without specifying the origin of country. Overall, in terms of the China, the migration flow is growing, and according to the Ministry of Education in 2017 it was amounted to about 17.5 thousand citizens of Kazakhstan.

The above statistics regarding Russia, tells us that over the past 8 years there has been almost a double increase in the flow of Kazakhstan students to Russia [10]. The flow of students to the preparatory remains at a stable level, so the bulk of the program is held in the branches of Russian universities in Kazakhstan. Undergraduate degree in Russia is more attractive rather than master's or $\mathrm{PhD}$ according to the statistics. The indispensable aspect of that phenomena is the easiness of enrolling the bachelor degree, for instance, in Russia, you do not need a certificate of Single National Testing and a certificate of language proficiency, it is enough to pass the internal exams of the university, which in comparison with universities in Europe and the United States is very surmountable and attractive. In Chinese practice, there is the possibility of free admission to language preparatory courses, after a year of training and a language exam, everyone with a sufficient level in language and basic subjects has the right to apply for a budget place. From the point of view of marketing, this strategy of struggle for the consumer wins in comparison with the countries of far abroad. By the way, students studying in Russia have a potential for citizenship, especially if the student is an ethnic Russian, and wants to go to the historical homeland.

The reason for choosing foreign education is also the availability of scholarship programs and opportunities for studying on a budgetary basis. There are grant funding programs for our students at different levels, and universities provide significant discounts for students on a paid basis. In addition, in foreign education systems there is an effective system of employment for graduates. And about $40 \%$ of students plan to further employment outside Kazakhstan through their places of residence and study.

Migration flows are formed annually during the main educational periods. September and June peak. The steady flow includes the total number of Kazakhstan students at all levels of education, and all countries of study, students of domestic universities, undergoing short-term internships abroad. 
It should be noted that coupled with the pushing factors, there are attractive factors as well. These are the policies of foreign countries in promoting their education systems. For example, the governments of China and the Russian Federation, conduct a pronounced, thoughtful, expansionist educational policy. It is enough to analyze the laws on education to make sure that "the state encourages and supports, and develops international exchanges and cooperation in higher education." Every year, foreign universities actively intervene in the Kazakhstan market of educational services, and the struggle for the consumer is gaining momentum, preparatory centers are being created, branches of universities are opened, joint international educational companies are created, and the faculty is being hunted. Meanwhile, international cooperation in education includes multilateral activities: - contacts of management and teachers, exchange of students, graduate students, doctoral students, internships, joint research, co-education. For Kazakhstan's higher education system, the rapid growth of migration flows is an alarming signal. Today, it is more important than ever to protect the domestic market for educational services.

In today's socio-economic environment, it is difficult for Kazakhstan to resist educational migration. Educational migration in general leads our country along the path of scientific progress and cultural enrichment. Much of it should be controlled and stimulated. The volume, composition and direction of migration flows are due to the level of integration of the country into the world's migration systems through education. By the way, integration into the world educational space is undoubtedly the merit of the state and society. I would like to point out that "international students" are a fundamental part of the global education system, which provides a significant contribution to the income of higher education. They also contribute to growing networks of transnational information and scientific networks, and enhance the exchange of achievements in science and technology, in teaching methods. Moreover, the internationalization of education leads to the formation of a new type of person, corresponding to the ideas of global citizenship.

But with a significant deterioration in social conditions, it is difficult to predict the level of real emigration and the growth of migration sentiments. Calculating the level of migration sentiment is not a tool to reflect real migration processes, but it allows to indicate the possibility of new migration flows and their characteristics, as well as changes of old in the event of political, economic, social and legal transformations within the country.

Researchers believe that countries and universities compete annually for educational migration flows, as international students are the key to constructive interstate cooperation, a way of influencing the educational (and, as a result, cultural, social and political) spaces of other states, as well as a source of high-quality work and intellectual contingents in the future. It is the international market for educational services that provides a source of highly skilled labour and specialized professionals in various fields. Those professionals who have graduated from higher education abroad have advantages such as tolerance, mobility, adaptability, knowledge of languages - therefore, they are more popular and competitive. The formation of specialists of this level should be a strategic task of the educational system [11].

Migration moods of Kazakhstani students of Hong Kong universities

It is necessary to divide migration moods into active and passive. Indeed, one group of people can actively prepare to leave the country (learn a foreign language, consult on emigration, seek a job abroad, etc.), and another can do nothing, limiting itself to declaring their desire to travel abroad. Accordingly, it can be concluded that the first group of persons will have an active form of migration mood, and the second group of persons - a passive form of migration moods. In this case, there will be two forms of behavior: active and passive. An active form of migration behavior is a potential emigration from the state. The most common steps taken by respondents wishing to travel abroad were to try to find a place of study abroad, collecting information about living conditions in the country of the supposed departure, studying a foreign language. However, the activity, which properly demonstrates the seriousness of the respondent's intentions to go abroad, consists, first of all, in attempts to find a place of study abroad, to apply to agencies and specialists in admission to universities abroad or to advise on migration issues, the registration of necessary documents for departure or relocation (visas, work contracts, work permits, etc.). The prevalence of migration is quite high. The overall prevalence of migration sentiment among young people in major cities and cities of republican importance is higher than in the province. For representatives of the regions, the priority is to move within the country, closer to accessible educational institutions.

The sociological survey was conducted for 132 Kazakhstan students studying in Hong Kong. This is one of the priority areas for educational migration from Kazakhstan. First of all, students are attracted by the quality of education. Here is a number of universities of the world box office, the five largest are in the top 100 "S 
World University Rankings Worldwide". Universities have a modern material base and a comfortable infrastructure. Students are trained in more than 150 current specialties. Furthermore, it is an international shopping and financial center, where the student can get professional connections. Many multinational corporations offer internships for hong Kong university students. Aside from that, the language of learning is one of the way to expand the geography of personal contacts of the student. Naturally, one of the main reasons for choosing Hong Kong universities is the availability of grants and scholarship programs for foreign applicants. In 2019, more than 250 students from Kazakhstan are studying, and the annual migration influx is 30-40 people [12].

About $70 \%$ of respondents showed migration activity and even applied to foreign institutions. However, only $40 \%$ of those with active migration are actively migratory and have chosen Hong Kong universities. Also, about $67 \%$ of respondents say they return after graduation, $26 \%$ aspire to emigrate, and $6 \%$ have not yet decided.

Most of the applicants studied in specialized schools 90\%, graduated Nazarbayev Intellectual School, The Republican Physics and Mathematics School, and the Kazakh-Turkish Lyceum. This distribution reflects an imbalance in general secondary education. In specialized schools, teaching is in English, funding allows to attract the best domestic teachers, and foreign teachers.

Ninety per cent of respondents' study through university grants or the Hong Kong budget, as well as international projects such as Wealth to Road, one road, one road. About 3 per cent are enrolled at a 50 per cent discount and another 7 per cent are enrolled free of charge but do not receive scholarships. The most popular paid specialties include business administration.

The distribution of respondents into the basic categories by cities of residence and study, revealed that the share of applicants from the two largest cities of Almaty and Nur-Sultan is about $98 \%$. This is due to the attractiveness of these places for highly qualified teachers, concentration of specialized schools. For example, in Almaty two KTL, RPMS, 2 NIS. In Nur Sultan 2 NIS, 2 KTL, RPMS. Almaty, 70\% became the leader in the total number of students. Another $2 \%$ of respondents studied in cities of regional importance.

Among those surveyed, 65 per cent were boys and about 35 per cent were girls. The predominance of guys is associated with the predominance of engineering specialties. And the average age was 20.7 years. And all the respondents are young people aged 18-22 years.

The educational migration in this case according to the surveyed, is mainly determined by four factors. The first is the prestige of Hong Kong universities on the international stage. The second factor is the opportunity to get a quality education for free. In third place in terms of frequency of the students' mentions were the direction of study, and a wide range of specialties. The fourth factor is the direct marketing work of universities to attract applicants during the professional orientation of the school graduate. Kazakhstan's specialized schools have extensive ties with Hong Kong universities, cooperating in the field of professional orientation and attract winners of international subject competitions through scholarship programs.

Thus, with a fairly wide and increasing prevalence of migration among young people, the proportion of potential educational migrants with a high probability of implementing existing migration sentiments is less than half. But even the level of active migration sentiment is not an indicator of possible emigration from these states. So, only half of the respondents with an active form of migration, took actions that clearly indicated readiness for emigration.

References:

1. A collection of materials from the conference "Global Challenges and Contemporary Trends in Higher Education Development" / G.N. Dzhaksybekova, S.Y. Intykbayeva, L.N. Gostenko / Almaty, 2013.

2. Educational migration from CIS and Baltic countries: potential and prospects for Russia / Under Ed. K.A.Gavrilova, E.B.Yatsenko. M.: Eurasia Heritage Foundation, 2012

3. Global Education Digest 2014: Comparing Education Statistics Across the World. UNESCO- UIS, 2015.

4. Lee E. A. Theory of Migration // Demography. 1966. № 1. P. 47-57.

5. Migration behavior and the migration mood of the population of the Republic of Belarus / A.I. Ambrajevic / Minsk /

6. stat.gov.kz 7. http://monitor.icef.com

8. chinapower.csis.org 
9. Exports of Russian educational services: Statistical collection. Issue 6 / Ministry of Education and Science of the Russian Federation. M.: Sociocenter, 2016. 408 s. 10. www.topuniversities.com

11. Shevtsova E.V. The main mechanisms of migration policy to attract training migrants: what Russia can learn from future world powers - NSUEU Herald. - 2012. - No1. S. 78 - 87. 12.

12. https://informburo.kz/. 